\title{
Protocol Deviation Code
}

National Cancer Institute

\section{Source}

National Cancer Institute. Protocol Deviation Code. NCI Thesaurus. Code C87991.

Symbol(s) used to designate specific protocol deviations. 